\title{
Learning alliance methodology: Contributions and challenges for multicultural planning in health service provision: A case study in Kent, UK
}

\author{
Carlos Moreno-Leguizamon ${ }^{\mathrm{a}}$, Marcela Tovar-Restrepo $^{\mathrm{b} *}$, Clara Irazábal $^{\mathrm{b}}$ and Christine Locke \\ ${ }^{a}$ Department of Health and Social Care, University of Greenwich, London, UK; ${ }^{b}$ Graduate School of \\ Architecture, Planning and Preservation, Columbia University, New York, USA; ${ }^{c}$ Diversity House, \\ Swale, Kent, UK
}

(Received 11 October 2013; accepted 18 November 2014)

\begin{abstract}
This article examines contributions and challenges of learning alliance methodology to multicultural planning in health provision services in an urban context. A learning alliance was implemented to target health needs of different ethno-racial groups through an action research project in Swale, Kent, UK. We argue that a learning alliance is an innovative methodology that can contribute to multicultural planning by (1) promoting the involvement of new planning stakeholders and the institutionalization of learning alliance outcomes, (2) ensuring capacitybuilding strategies, (3) emphasizing documentation and dissemination as innovative practices, and (4) strengthening the network capacity of a community. Critical reflections are presented here as a constructive view to improve both the learning alliance methodology and multicultural planning. The article contributes to debates on public service delivery in the context of discussions about multiculturalism, health and planning.
\end{abstract}

Keywords: Learning alliance methodology; multicultural planning; Kent-UK planning; health services; black and minority ethnic groups (BME)

\section{Introduction}

What can learning alliance methodology offer to planning policy and practice in multicultural communities? How can planners develop cultural competency to integrate "difference" into planning practices and participatory actions in a comprehensive way? (Agyeman \& Erickson, 2012; Sweet \& Etienne, 2011; Vazquez, 2009). This article examines a health action research project implemented in the Swale District (Sittingbourne, Kent, UK) in 2009-11. The research problem centred on how black and minority ethnic $(\mathrm{BME})^{1}$ groups were being included within health planning processes by the local planning authorities. In 2008 the Department of Health released the report "No patient left behind: How can we ensure world class primary care for black and minority ethnic people?" in which difficulties experienced by BME communities regarding primary health services in the UK were discussed (Department of Health, 2008). Taking into account these results, the general aim of the project was to obtain knowledge on diversity issues related to the health and social care needs of BME populations in Swale by using a learning alliance methodology. The specific objectives were as follows: (1) mainstreaming training and capacity-building in the areas of equality and diversity through various stakeholders, (2) mapping out the main BME health needs in Swale and elaborating an in-depth wellbeing health assessment, (3) documenting the process of launching, developing and monitoring learning alliance methodological techniques to plan urban interventions in response to the health and social care needs of BME populations in the project area, and (4) promoting networking to guarantee the sustainability of the project.

\footnotetext{
*Corresponding author. Email: mtovar1967@yahoo.com
} 
This project was formulated and carried out simultaneously with the passing of the UK's Equality Act 2010, which integrated, in one act, the separated histories of struggle against inequalities and discrimination. Briefly, in the UK this struggle started in the 1960s with the (gender-) Equal Pay Act passed in 1970, continuing later with the Disability Discrimination Act 1995, the Employment Equality (Religion or Belief) Regulations 2003, the Civil Partnership Act 2004, and the Employment Equality (Age) Regulations 2006. In many ways, the UK equality history parallels other instances such as the civil rights movement in the USA and the post-2000 transformation of equality regimes in Europe when including "discrimination on grounds of race and ethnicity, and on grounds of age, disability, sexual orientation, and religion, thus extending its previous gender-only equality policy" (Krizsan, Skjeie, \& Squires, 2012, p. 2). The Equality Act's adoption has had important consequences for planning authorities and providers of services, since it requires local authorities to assess, include, and monitor all strands included in the Equality Act. This has prompted them to promote and endorse more inclusive planning methodologies and strategies. These changes provided an interesting background for the project because it challenged the way in which ethno-racial diversity had been defined in the past as a source of discrimination isolated from other marginalizing identity markers such as gender, religion, and disability.

The framework by which the Equality Act has been inspired echoes the arguments raised by the body of literature on intersectionality (Crenshaw, 1989; Davis, 1981; Hill Collins, 2009; Irazábal \& Huerta, 2014; Lorde, 1985), which seeks to address multiple forms of discrimination based on diverse and intersecting identity markers such as gender, income, ethnicity, race, and age. This approach challenges multicultural planning practitioners who see ethno-racial and cultural diversity in isolation by pointing out the interdependence between ethnicity, race, and other categories of domination or subordination when defining the needs and interests of individuals (Anthias, 2002; Anthias \& Yuval-Davis, 1983; Brah \& Phoenix, 2004; Burman, 2003). Nevertheless, feminist scholars have continued to call attention to the lack of a more integrated methodology to address such intersectional complexity (Bastia, 2014; McCall, 2005; Nash, 2008). In their view, this methodological question remains a contingent and unresolved issue for planners and policy-makers, who need more specific tools to respond to intersectional planning challenges.

Diversity has been a highly debated issue that poses questions for planning methodologies and conceptual frameworks. Persistent challenges in terms of how to identify, target, and satisfy the needs of culturally different groups by equitably integrating them into a more inclusive society have no definitive solutions. The fluid, changing, and complex nature of identity markers and their correlation with unequal power and social relations constitute key challenges for any approach or methodology in planning. The dangers of naturalizing differences, reifying group identities, and isolating race and ethnicity from other intertwined identity markers that may trigger discrimination or privilege and affect the daily life of individuals, still confront planners.

By looking at this health planning experience using learning alliance methodology, this article sheds light on these issues. We argue that a learning alliance is an innovative methodology that can contribute to multicultural planning in the following ways: (1) it requires the involvement of local planning authorities and policy-makers to guarantee the mainstreaming and institutionalization of learning alliance outcomes, (2) it ensures a participatory and sustainable planning process through training and capacity-building strategies implemented with BME groups, (3) it emphasizes the need for documentation and dissemination of projects' results among stakeholders, including academics, civil society organizations, planners, and health practitioners, and (4) it strengthens the network capacity of a community to guarantee the sustainability of the project. We also point to the learning alliance's important limitation as a multicultural planning tool; it does not include a multidimensional and in-depth social analysis of diversity and intersecting identities, an omission that may reinforce forms of discrimination during the identification and assessment of health needs and services. We end by offering recommendations to overcome this flaw. 


\section{Multicultural planning}

Multicultural planning focuses on appreciating and working with the differences in cultural groups' epistemologies and practices rather than prioritizing scientific knowledge above local knowledge (Sandercock \& Lyssiotis, 2003; Umemoto, 2001). It involves targeting "the culturally defined needs of ethno-racial minorities on the one hand, and reconstructing the common ground that underlies policies and programs on the other" (Qadeer, 2009, p. 10). It considers cultural groups who have not been equally represented in urban planning by opening participatory spaces where they can express their diversity, make more autonomous decisions, and manage and plan for their communities with government support (Jojola, 2000; Lane \& Hibbard, 2005; Marlor, 2010; Porter, 2010; Umemoto \& Zambonelli, 2012). It follows the planning tradition of moving beyond knowledge and empirical data to community actions based on more qualitative data and social learning (Friedmann, 1987).

Multicultural planning is grounded in identity politics. It focuses on social groups with selfidentified interests, emphasizing the existing power relations between them and the dominating society. It looks at the way in which politics and access to resources, decision-making forums and opportunities are shaped by identity markers such as gender, ethnicity, race and class. In this perspective, identity markers not only shape the subjectivities of individuals and social groups, but also inform experience and social practices that trigger forms of discrimination or privilege. Social movements that became active during the late 1960s, such as the ethno-racial minorities' or women's movements, have been associated with this perspective. However, critics of this perspective have argued that it has often seen identity as discrete and fixed rather than hybrid, fluid, and dynamic, allowing strategies such as "strategic essentialism" to be used by social groups to politically position themselves (Tovar-Restrepo, 2014). In consequence, this approach runs the risk of assuming false and simplistic generalizations about subjects and subjectivities and their social and power relations (Anzaldúa, 1987/1999; Appiah \& Gutmann, 1996; Fraser, 1997; McNay, 2008; Spivak, 1988).

The main contribution of multicultural planning is to raise awareness of different cultural views, experiences, historical backgrounds, and needs of diverse groups who have been overlooked in terms of their access to city rights, services, and participation. It tries to ensure more equitable and democratic participation by removing obstacles that have prevented minorities from becoming involved in citymaking processes (Corburn, 2003; Fainstein, 2000; Irazábal \& Farhat, 2008). Through multicultural planning, new views on ethno-racial groups' identity politics and actions can be propounded by changing stereotypes and stigmas (Irazábal, 2011), for example, by enhancing the economic potential of their business activities and making visible their work contribution to local economies (Bubinas, 2005; Irazábal \& Gómez-Barris, 2007; Miraftab, 2011; Miraftab \& McConnell, 2008).

Multicultural planning has its challenges. Empirical research among UK local authorities reveals that ethno-racial issues have a low priority on their agendas (Beebeejaun, 2006, 2012; Loftman \& Beazley, 1998; Thomas, 2000). Uncritically recognizing groups defined by ethnicity or race is not coterminous with equality. On the contrary, it may reinforce racist stereotypes and naturalize cultural differences (Irazábal, 2012). Beebeejaun (2012) reasonably argues that in most cases ethnoracial identity is presumed to be self-evident for planners and that little attention is paid to key issues such as the way in which groups are identified and self-identified, and how their power and hierarchical relations are structured. This approach may hide the complex, multiple, overlapping, conflicting, asymmetrical, and fluctuating power relations among group members (Irazábal \& Huerta, 2014; Irazábal \& Punja, 2009). Moreover, Sandoval (2013) highlights how, in the USA, multicultural planning may inversely affect undocumented immigrant communities in which the private sector and local government officials turn a blind eye to new migrants' legal status in favour of the benefits of a cheap, endless labour pool for employers, rental income for landlords, and property and sales taxes for local government within the area surrounding the places of work where the employees and their affiliates settle (Carpio, Irazábal, \& Pulido, 2011; Yiftachel, 1998). 
Industrialized countries such as the USA, UK, Canada, and Australia have applied multicultural planning to accommodate cultural diversity on a case-by-case basis, particularly in large and medium-sized cities (McClinchey, 2008; Qadeer, 2009; Qadeer \& Agrawal, 2011; Ram, Abbas, Sanghera, \& Hillin, 2000; Yiftachel, 2009). In Canada, multiculturalism is legally sanctioned, centring on ethnicity and race, national status, and language groups. In this country, as in the USA, multicultural planning is used to intervene in ethno-racially and linguistically diverse communities to provide government support and service provision (Jones, 2010; Ram et al., 2000). Multicultural planning also serves indigenous populations' aims of expressing their cultural diversity via selfdetermination to manage and plan for their communities (Jojola, 2000; Lane \& Hibbard, 2005; Porter, 2010). In the case of Australia, the Australian Public Service Commission has formulated a Multicultural Plan 2013-15 to ensure the satisfaction of the needs of culturally and linguistically diverse communities by implementing the Multicultural Access and Equity Policy.

In the particular case of the UK, ethno-racial diversity came onto the planning agenda in the late 1960s and early 1970s, although other important attempts were made earlier. Beebeejaun (2012) and MacLeavy (2008) identify three different ways in which the UK planning system has considered ethno-racial minorities and diversity. The first moment was during the post-World War II era, when ethno-racial diversity took the form of perceiving immigrants as a challenge to British national unity, and planning efforts centred on groups living in deprived areas. This was a "compassionate" approach centring on spatial issues such as overcrowding, poor housing standards, and rent discrimination. Propelled by the Urban Programme in 1968 and anti-racial discrimination legislation (i.e. the Race Relations Acts of 1965 and 1976), the UK then began to focus on greater racial justice, a perspective characterized as multiculturalism. This second moment attempted to manage distinct ethno-racial and immigrant groups informed by contributions based on identity politics frameworks. Its approach sought to merge ethno-racial diversity considerations with other planning traditions, rather than concentrating simply on land use, housing, and spatial planning. It targeted culturally diverse groups, placing special emphasis on historically important immigrants: Africans, West Indians and Asians (Indian, Bangladeshi, and Pakistani). This approach began to be questioned in 2000 for generalizing and essentializing difference, encouraging selfsegregation, and failing to include diversity effectively in British life.

A call for a different approach then emerged. It is characterized as "diversity and community cohesion" and aims to encourage integration, focusing on inclusionary techniques (Beebeejaun, 2012, p. 531; Community Cohesion Review Team, 2001). This approach moved away from identity politics frameworks to recognizing people's individuality.

The project analysed here sought to create a platform where "differences" were expressed and institutionally recognized through the learning alliance. Building on multicultural planning, it emphasized the participation of different ethno-racial groups, among other stakeholders, in order to voice their needs and interests, through a monitored and documented process that disseminated its findings and institutionalized them into plans. By following the learning alliance methodological steps, this project made the following contributions to multicultural planning: it involved local authorities as actors who are empowered to bring mainstream diversity into planning; it implemented capacity-building strategies among different stakeholders; it disseminated the project outcomes; and it strengthened community network capacity to ensure sustainability of the planning process, as explained below.

\section{The National Health Service and the BME communities in the context of the project in Swale}

In the UK, the National Health Service (NHS) has the mandate to guarantee non-discriminatory planning processes for ethno-racial minorities through all its planning of health services based on, inter alia, the philosophy of multicultural planning. However, the NHS has been criticized for 
failing to take into account BME communities, as found by Professor Lakhani's committee investigation for the Department of Health (2008):

A significant proportion of BME patients are struggling to get the health care they need. They are afraid to complain about poor services and unable to exert real influence on improving local services ... There is a deficit in the commissioning and procurement of primary care, such that services are not provided for or planned for according to need. (p. 3)

The NHS delivers health services throughout the UK. It is of great cultural significance to English society for being historically among the few institutions available to all citizens based on need rather than ability to pay. It is tax-funded and free at the point of delivery. Clear evidence of this significance can be found in the tribute paid to the NHS during the opening of the Olympic Games in London 2012, in which the NHS played a central role in the ceremony of inauguration. ${ }^{2}$ Similarly, NHS relevance is reflected in its regular presence in the UK media, where it is used as a metaphor to express the current political debate between the political "left-wing", "centre" and "right-wing" positions on health service delivery.

The NHS budget represented $8.4 \%$ of the UK gross domestic product in 2010, with an annual budget of more than $£ 100$ billion according to Blumenthal and Dixon (2012). However, since the financial crisis of 2008, the NHS has entered a new period of austerity combined with reforms. Among them, for example, is competition from providers of healthcare services based on price, quality, and safety, as well as decentralization of all public health service functions to local authorities since April 2013. In the Strategy for Public Health in Kent in 2008, local authorities along with the NHS primary care trusts (phased out in April 2013) identified several areas of health needs for this county of 1,394,700 people (mid-2007 population estimate, Department of Health, 2009a). They were: the reduction of health inequities, heart disease, teenage pregnancy, substance and alcohol abuse, the improvement of the mental health and well-being of children, sexual health, and the care of older people with chronic conditions living at home (Kent County Council, Eastern and Coastal Kent NHS Primary Care Trust, and West Kent NHS Primary Care Trust, 2007).

The Swale District of Kent had a total population of 128,500 according to the 2001 UK Census, $2500(1.86 \%)$ of whom were classified as BME (Office for National Statistics, n.d.). The mid-2007 population estimate was 130,300 (Department of Health, 2009b). Swale had a total population of 136,300 as per the latest Census in 2011, 4433 (3.45\%) of whom were classified as BME (Maidstone Borough Council, 2011). These numbers indicate that Swale was experiencing an influx of minority people.

In the health profile of Kent in 2009, the districts of Swale and Thanet were reported as having the highest proportions of people living in deprived neighbourhoods. Similarly, Swale was reported as having a lower life expectancy for women (81 years) when compared to Kent (81.1) and England (81.8) (Department of Health, 2009a). Additional research on health services access and provision in the UK, including Swale, indicated that there was a predominant mismatch between the health needs of BME people and the health services on offer locally (Department of Health, 2008). This evidence, together with the experience of health service provision recorded by Diversity House (DH), a local non-governmental organization (NGO) in Swale (or a charity, as denominated in the $\mathrm{UK}$ ), inspired the organization to create a project focused on the improvement of health and social care services for Swale's BME communities. The fact that the project was an initiative by a charity rather than by the NHS, which is the authority in charge of leading these types of projects, evidences the lack of attention given to BME groups in the area, confirming what was pointed out in the literature on multicultural planning (Beebeejaun, 2006, 2012; Loftman \& Beazley, 1998).

The project determined that, in order to increase health innovation and knowledge transfer to BME groups in Swale, the use of learning alliance methodology was appropriate. Changes occasioned by the Equality Act in 2010 were not included in the project because the bill was sanctioned after the project had been formulated and initiated and local authorities were 
incognizant of its contents. However, the project used the BME category to target the issue of ethno-racial diversity, given the legislation in place in 2009 in relation to ethno-racial diversity, and it facilitated one of the first presentations of the Equality Act carried out locally by the Equality Human Rights Commission.

The project was implemented by Diversity House in Swale between January 2009 and January 2011. This organization's mission was to assess and improve the Swale BME community's health needs. It funded $73 \%$ of the project whilst the remaining $27 \%$ of its total running costs came from the South East Coastal Communities (SECC) project funded by the Higher Education Funding Council for England (HEFCE). The SECC's general goal was to promote collaborative work between nine universities in south-eastern England and their local communities.

In the early phase of the project formulation the Faculty of Health and Education of the University of Greenwich supported Diversity House. The university provided one academic facilitator for the learning alliance as well as methodological skills. Other significant stakeholders of the project included Kent Adult Social Services, East Kent Area Equalities Group, planning and management local authorities from the Swale Borough Council, Eastern and Coastal Kent NHS, Kent Fire and Rescue Service, and Swale's Council for Voluntary Services and Volunteer Centre.

\section{Learning alliance: methodology and methods}

Gotrett, Lundy, and Ashby (2005) state that there are two main approaches to research. The "mode one" type is characterized by being lineal in the production of new knowledge. Here, researchers are accountable and obtain legitimization of their knowledge chiefly from their peers. Although successful in many instances, this type is currently regarded as having limitations derived from its disregard for the multiple sources from which knowledge is produced, its diversity and multidisciplinarity, the partnerships that in many cases contribute to its production, its organizational and socio-cultural contexts, its sharing and ownership (individual and collective), and above all, its impact on the transformation of people's lives (Moreno-Leguizamon \& Spigner, 2011).

The "mode two" type of knowledge production, on the other hand, is characterized by its promotion of the interaction of "multiple actors with multi-layered sources of knowledge to cope with the complexity of fostering continuous technological, social and institutional innovations to respond to rapidly changing context and demands" (Gotrett et al., 2005, p. 2). The learning alliance approach grew up under the assumptions of the "mode two" type. It has emerged as an actionresearch methodology that seeks to bring together academia, local authorities, policy-makers, researchers, civil society organizations, and hard-to-reach groups and institutions. "Hard-to-reach groups" is a term used by providers of various services in the UK to characterize groups of people with whom it is traditionally difficult to establish relationships.

Early influences on the origin of the learning alliance approach come from managerial theories on innovation in the private sector, organizational learning, and strategic alliances (Butterworth, McIntyre, \& da Silva Wells, 2011; Inkpen, 2000; Khanna, Gulati, \& Nohria, 1998; Koza \& Lewin, 2000; Morrison \& Mezentseff, 1997). Without pretending to be radically innovative, as stated by Moriarty, Fonseca, Smits, and Schouten (2005), the learning alliance approach attempts to incorporate the lessons learnt from research limitations in the areas of poverty alleviation and all types of planning and delivery of services to low-income communities in general, and in sectors of agricultural and urban water management in particular.

In developed countries, the application of the learning alliance approach is limited. In the case of the UK health sector, learning alliances have not been implemented. This article is the first to analyse the experience of implementing a learning alliance in the south-east of England for the provision of health services to BME communities. 
Despite its potential for having different areas of focus, prompting criticisms in the literature that it lacks a standard definition (Locke, 2009), a learning alliance is commonly defined as a series of connected multi-stakeholder platforms or networks (practitioners, researchers, policy-makers, activists) at different institutional levels (local, national) involved in two basic tasks: knowledge innovation and its scaling up in time (sustainability) and space (coverage) (Butterworth et al., 2011; Moriarty et al., 2005; Smits, Moriarty, \& Sijbesma, 2007; Verhagen, Butterworth, \& Morris, 2008; Penning de Vries, 2006).

Emphasis on innovation as opposed to invention is very significant for a learning alliance, since this refers to the mechanism by which the relations, interactions, and activities between and within the various stakeholders produce and adapt knowledge. Specifically, in terms of research practice, the innovation angle translates into putting research findings into use rather than always implementing new research, although the latest type of research is plausible as well. Meanwhile, "scaling up" refers to widespread replication of an innovation, while ensuring its quality and sustainability (Moriarty et al., 2005, p. 8).

A learning alliance does not require the development of a new formal research process to gather primary information, as in action research (primary information is not essential when valid and accurate data are available); it enforces mutual cooperation for all vertical and horizontal learning, it includes diverse actors, roles and organizations at multiple levels, it addresses institutional constraints and enhances institutional learning, it avoids the traditional division between research outcomes and processes, and it integrates innovations, scaling up and dissemination. Methodologically, a learning alliance makes use of stakeholder analysis, capacity-building, action research, process documentation and dissemination, and process-monitoring according to context and needs (Locke, 2009). However, a learning alliance is more than the sum of these methodologies.

Action research is an important component of a learning alliance (Butterworth et al., 2011). Similarly, the traditional cycle of performing action research comprises a set of interrelated actions: planning, action, observations, and reflection. Nevertheless, compared to the action research approach, in which the participation of policy-makers and planners may be optional, in a learning alliance their participation is compulsory in order to guarantee the legislative platform to transform research findings into policies and programmes.

\section{Findings}

Attending to some of the principles of multicultural planning - such as attention to ethno-racial groups, their participation in planning processes, and their equitable access to services - the project sought to encourage participation of ethnically and racially diverse individuals, guaranteeing them a democratic space where their differences and experiences could be expressed, validated, and translated into health planning interventions in an interactive process. We discuss the main findings in relation to the various components addressed by the learning alliance: training and capacitybuilding, use of previous research reports, research activities (focus groups, formal and informal interviews, BME summits, electronic survey on provision of BME services by local organizations), and networking.

Training and capacity-building took place through a total of 13 workshops run during a period of 20 months on two levels: internal and external. The internal capacity-building was for the volunteers and staff of Diversity House, who were predominantly BME people and who had the responsibility of conducting the data collection and implementing the other components of the learning alliance. Volunteers also gained skills in framing survey questionnaires for the various research activities, facilitating groups, giving presentations, and providing leadership. The external capacity-building was directed at local organizations that provided health and social care services, 
and at other project stakeholders such as planning authorities from Swale Council. All the activities under these components aimed at building capacities to identify and understand causes of and appropriate ways of dealing with Swale BME inequities in health and social care. The underlying rationale here was to move beyond research and knowledge to establish sustained community actions, as stressed by multicultural planning (Friedmann, 1987). Capacity-building at the external level, that is, for other local organizations, was performed with the purpose of obtaining financial sustainability for Diversity House. Two training packages were developed: the first on multicultural proficiency in planning local services, and the second on equality and diversity health issues. During the time span of the project, Diversity House sold these packages locally. Clients included the local council and social care organizations. As of June 2014, Diversity House has been successful in sustaining itself financially through the marketing of these packages.

Findings on the training and capacity-building component of the learning alliance permitted the observation that, in order to guarantee future sustainability, financial and otherwise, of a local NGO or charity, capacity-building must go beyond knowledge and research to include fundraising as a key activity. In the UK, local NGOs and charities sustain themselves by appealing for donations and grants rather than marketing their knowledge, experience, and research skills. This experience shows how Diversity House has positioned itself as the only NGO or charity in Swale working and selling knowledge services on BME issues. The local council recognized Diversity House as the best charity of 2013. Differently from a mode-one research model, a learning alliance leaves an important legacy for the community once a project is complete. For many planning and policy researchers and practitioners, their work legacy represents an ethical dilemma that a learning alliance could help to resolve.

The second component, as recommended by a learning alliance, consisted of using previous research findings about the identified health needs of some BME groups in Swale. Diversity House had been involved in research on the African-Caribbean community in Swale (Locke, 2006). Additional available research investigated the Chinese community (Yau \& Turle, 2005) and the gypsy and traveller communities (Smith \& Ruston, 2009). The main health needs reported for the African-Caribbean people in Swale were as follows: injuries from race and hate incidents; negative attitudes of some general physicians' (GP) receptionists; a very long waiting time for ambulance response and the negative attitudes of some ambulance staff; lack of cultural understanding and awareness; and lack of involvement by the local authority on health and care services. The lack of opportunities for local employment was also stressed as a felt need that was correlated to health issues (Locke, 2006). Meanwhile, health needs identified for the Chinese community were related to difficulties experienced by health and social care services in assessing their needs because of language barriers. Language translation was identified as the main issue, since most of these individuals spoke Cantonese and would have required interpreters to access health services and providers. Similar findings were concerned with a culturally sensitive understanding of their notions of health and illness (Chau \& Yu, 2009).

The major health needs identified for the gypsy and traveller communities were: difficulties in accessing health education, lack of housing, difficulties in registering with $\mathrm{GPs}^{3}$ and dentists related to their mobility, continually being blamed for illegal activities (e.g. fly-tipping, thefts), constant racial and verbal abuse and discrimination, unemployment, and negative experiences of dealing with social care agencies. Similarly, it was observed that many public bodies failed to include gypsies and travellers in their monitoring systems, given their lack of cultural awareness training and lack of flexibility in service provision (e.g. enabling female patients to see female doctors and keeping a register of local GPs in each area that roadside travellers might access) (Smith \& Ruston, 2009).

The significant aspect of putting these previous research findings "into use", as recommended by a learning alliance, was that they resonated with both multicultural planning literature and other 
national research studies looking at health needs of BME groups in the UK (Kai \& Hedges, 1999; Salway, Platt, Chowbey, Harriss, \& Bayliss, 2007). Multicultural planning helped practitioners to understand that in order to target health needs experienced by diverse ethno-racial groups they must be framed by their different worldviews and epistemologies, forms of knowledge, and practices (Umemoto, 2001). In other words, it is crucial to take into account the diverse cultural meanings of key notions such as pain, primary attention, proper care, and bodily expressions in prevention, diagnosis, and treatment in order to guarantee the well-being of all health users. The local reports on which we relied were strongly linked to national issues addressed by the literature on health needs among BME groups in the UK, as stated in the Department of Health (2008) report.

Research activities, as a third learning alliance component, were performed through two BME summits, four focus groups, five formal interviews with BME community leaders, some informal interviews, and an electronic survey administered to 22 local organizations offering services to BME communities. Corresponding ethical approval was obtained for those activities. Approximately 220 BME people and 22 organizations providing health and social care services were consulted through the various research activities. The ethno-racial groups who were consulted were the African-Caribbean community, the South Asian communities (of Bangladeshi and Indian origins), and the Chinese community. Other communities present in the area such as the gypsy and traveller, Turkish, Filipino, and Polish communities were difficult to attract, even though the project engaged with key representatives from these groups.

Ordered from most important to least important, the main issues identified were language barriers, concerns about GPs attention, lack of access to GPs in community health centres, lack of information due to time constraints, rude attitude of GPs' receptionists toward BME individuals, slow speed of referrals, need for more cultural competency (e.g. female GPs for female patients), and need for holistic screenings (e.g. diabetes checks).

Research subjects unanimously concurred that generally GPs do not give information to their patients on important health issues, such as the side effects of prescribed medication. They stated: "GPs need to spend time talking about medication and side effects." GPs are said to lack the knowledge required to meet the needs of BME service users; e.g. "nomadic gpsies and tavellers find it difficult to register with GPs and dentists. This is because of lack of permanent residency." It was also commonly agreed that most GPs do not like referring their clients for specialist help, such as screening for the main diseases and health conditions suffered by BME people, including diabetes and heart risks. Moreover, GPs receptionists were found to be rude to BME service users. They responded negatively when different language accents were perceived in patients. Interviewees stated that speaking non-dominant languages prevented people from using services available to them.

More women than men took the time to provide information for research activities. However, given that consultations mainly focused on ethno-racial diversity and disregarded the gender perspective, the information gathered did not allow us to explicitly differentiate between men's and women's health needs. In addition, neither gender roles nor interests were identified and differentiated when taking into account religious affiliations. For example, it was more difficult to persuade South Asian Muslim and Hindu women to actively and publicly express their views than Christian African women, who made more public statements, offering their opinions and perspectives. Similarly, tensions between some South Asian men and some African women mediated most meetings, given that the latter would make more spoken statements than South Asian women, who commonly express their views through their husbands' voices. Similarly, it was notable that South Asian men substantially outnumbered women in leading positions in local organizations and as local authorities in councils, undermining women's participation. A potential explanation for this is that the South Asian communities have been in Kent for longer than the African-Caribbean communities, who have been moving into this area more recently as a result of the high housing costs in London. Clarke and Stokes (2008), examining the representation of BME 
councillors in London boroughs, state that "in 1981-1991, Black Africans, Black Caribbeans, Bangladeshi, were the most concentrated in the inner metropolitan area, followed by Pakistani, Other Asians, Black Other, and Indians. In 1991-2001, there was a turnaround: all these groups except for Black Other and Other Asians joined the deconcentration trend, with declining shares of the city population and growth in the outer boroughs" (p. 4).

The findings described above were corroborated by the literature on both multicultural planning and BME health needs regarding issues such as gender roles, religious affiliations and ethno-racial identities. For example, Dargan (2007, 2009) and Greed (2005) have noted that many urban planners frequently understand and address communities as homogenous entities, specifically ignoring the voices of women and other minority groups (Irazábal \& Huerta, 2014). It was incorrect and insensitive of the project not to take into account the gender perspective when focusing on ethnicity and race. Furthermore, as Yuval-Davis (2007) has highlighted, the importance of religious affiliations in the performance of gender roles is crucial when different groups of women are interacting. She suggests that the issue of "minorities within the minorities" should be addressed, an important mandate that both multicultural planning and learning alliance try to tackle. Although of palpable significance, religious affiliation was not given a significant role in the project.

The main finding observed in the electronic survey among local organizations providing services to BME communities was that, out of the 22 organizations that were consulted, only 13 responded. Of those, only nine were using the ethno-racial categorization as required by UK legislation and enforced by the Home Office in the 2001 Census, which was Indian, Pakistani, Mixed Race, Black Caribbean, Black African, Bangladeshi, Other Asian (non-Chinese), and Chinese. The other four organizations were generally categorizing individuals as BME and nonBME. For a relatively small area such as Swale having four organizations not monitoring BME data as per the legal requirement was significant.

Collecting and monitoring data on health and care services provided to BME individuals is a contested issue in the UK. By law, any UK organization providing services is obliged to collect and monitor data on ethnicity and race as per the Race Relations Amendment Act (2000). Ethno-racial monitoring in the UK is the compulsory process by which employers and providers of social services collect, store, and analyse data about people's ethno-racial backgrounds in order to identify inequalities and their causes (Office for National Statistics, 2003). In the case of this project, local authorities frequently argued that, according to the Census of 2001, few BME people lived in the area; however, as we have shown above, this population is growing and was already representing a significant group according to the 2011 Census.

Finally, networking, the last component suggested by learning alliance, enabled the consolidation of a network of 16 different organizations, including community-based organizations (CBO), charities, and governmental institutions. These organizations were asked to flag BME inequalities for local authorities and planning bodies, present proposals for BME careers, and advise Kent public services such as the Fire and Rescue Service. As of 2014, this local network is working to illuminate BME health issues in this area.

\section{Discussion}

The main findings of the project related to (1) the learning alliance and multicultural planning as methodologies, (2) the role of stakeholders in the planning and research process, (3) the role of documentation in a research project, and lastly (4) resources. These findings contribute to the search for innovative methodologies that would enrich the current practices of multicultural planning.

Although learning alliance and multicultural planning provide important insights to address social diversity and unequal power relations between social groups, neither of them present analytical or methodological tools to fully capture the complexity of intersecting forms of identity 
and power inequalities present in multicultural societies (Bastia, 2014; Matsuda, 1991; Nash, 2008). In particular, in this project race and ethnicity were addressed in isolation from other subordination categories such as gender, religion, language, and national origin, leading to an incomplete identification of health needs, forms of participation, and provision of health services. It reproduced the common methodological and conceptual flaws that do not consider the various categories of oppression as interconnected and interdependent, but as separate essentialist categories privileging one system of oppression over another. It ignored the impossibility of explaining inequalities through a single framework of oppression as Valentine (2007) has observed.

For example, in the context of this project the learning alliance methodology tended to use categories such as "community" and "health service recipients" as uniform bodies, without unpacking the existing differences within them. This prevented the project from taking into account gender differences, which is one of the most encompassing and ubiquitous forms of subordination. Assessing differentiated gender roles, access to resources and opportunities, subjective contents, and perception of experience was key to addressing inequalities and avoiding the reinforcement of oppressive gender roles or other forms of inequity (Lutz, Herrera Vivar, \& Supik, 2011). Moreover, acknowledging and producing accurate gender and ethno-racial desegregated data would have been necessary in order to capture the existing dynamics of exclusion between race and gender (Maynard, 1994). ${ }^{4}$ The lack of gender perspective and intersectional analysis prevents researchers and planners from effectively identifying needs and interests based on ethno-racial and gender roles or conceptions. In this case, key issues in the health service, such as family relations or notions of the body, health, disease, or intimacy, were not sufficiently explored. As documented by Babatunde and Moreno-Leguizamon (2012), women as health service users have to be addressed within the complexity of relations to their domestic sphere, family politics, and other forms of inequity such as lack of assets and economic resources.

The project sought equal participation by all the existing ethno-racial groups in the area as validated by the multicultural planning literature (Qadeer, 2009; Umemoto, 2001); however, despite efforts to reach out to all the different groups, some did not participate in the process due to language barriers, lack of community leadership, and tensions with other ethno-racial minorities. Members of some groups, such as the gypsies, felt the exclusion of their group was discriminatory. Some interviewees expressed some dissatisfaction with the attitude of Diversity House. They felt that the project management should have focused more on promoting the welfare of all BME groups, and not mainly the Africans. The ethno-racial and gender tensions identified showed that it is crucial to take methodological measures to guarantee that everyone is included and is able to express opinions and views freely without being subjected to hierarchical dynamics among the different groups. This brings forward the question of minorities within minorities that Yuval-Davis (2007) has pointed out, noted above. It is a challenge very much in need of theoretical and methodological problematization, yet in the project it might have been met by running independent interviews and focus groups with each group, and encouraging women and men to participate equally in community groups or organizations. Despite these omissions the learning alliance project opened new opportunities for stakeholders to consider some of the gaps in their practices, in particular the way in which ethnicity, race and performance monitoring had hitherto been recorded.

The case study presented here shows the need for institutional commitment from all the participating stakeholders in a learning alliance from the very beginning. This is particularly important when the leadership of the LA is a charity organization or an NGO rather than a local planning authority. Mainstream views tend to regard national and local planning bodies as the main actors in community decision-making processes. However, other stakeholders, such as Diversity House in this case, can become dominant planning actors and knowledge producers. The implementation of the project confirmed that stakeholders who are not institutionally or formally involved in formulating municipal plans can play a significant role in identifying needs and 
providing health and care services to minority groups and immigrants (Kotin, Dyrness, \& Irazábal, 2011). Of course, who is the knowledge producer is a contested issue when it is obvious that knowledge (research) production is no longer the domain of academic centres but also of charities or NGOs, the private sector, and even governments. The project provided an excellent opportunity for new actors and experiences such as a service-learning practice that contributed to new forms of knowledge production (Harris \& Irazábal, 2012). Swale offered the university the opportunity to embark on strategic engagement with communities that had little experience of working with institutions of higher education. Focusing on such a tightly defined geographical area also allowed the university to have a demonstrable impact. The project enabled Diversity House to consolidate itself as a charity organization and obtain further funding for BME communities.

Another methodological contribution made by this case study is documenting how research is implemented in order to capture changes in practice. Interestingly, the marked division between research findings and their translation into practice is addressed by the learning alliance. As a learning tool, documenting the process had positive effects for Diversity House. It enabled this charity to organize and document its daily activities, structure its work plans, schedule training events, and systematize other organizational issues such as collecting data, logging phone calls, counting visitors, and disaggregating information on gender and ethno-racial bases. In its turn, this contributed to fundraising. The learning alliance differs from multicultural planning in this regard. While multicultural planning does not pay specific attention to documentation beyond academic considerations, learning alliances seek to complement the academic aspect by using documentation as a way of consolidating and restructuring the organizational culture of the different stakeholders involved in the process. In this particular case, the learning alliance made Diversity House aware of its knowledge and procedural bases and thus assured sustainability.

Finally, as with any successful methodological tool, learning alliance required adequate financial and human resources in order to plan, organize, and properly document and disseminate activities and outcomes. All these components are needed in order to guarantee the sustainability of the positive planning legacies. Distinct from multicultural planning, a learning alliance places special emphasis on the need to guarantee financial and human resources for the long-term sustainability of its projects, a goal achieved at Diversity House.

\section{Conclusions}

By implementing a learning alliance methodology as a "mode-two" type of knowledge production (Gotrett et al., 2005), this case study allowed us to identify contributions to planning policy and practice in multicultural communities in order to address current inequalities. Learning alliance is an innovative approach in Kent's health planning; it has brought positive outcomes and changed the attitude and perceptions of various organizations and stakeholders concerning planning in a multicultural context. The study also identified methodological limitations and challenges of concern for planners, who must meet new inclusiveness requirements specified in UK legislation and existing in diversified communities.

Based on this case study, the contributions from learning alliance methodology to multicultural planning can be summed up as (1) involving local authorities who are empowered to institutionalize and mainstream diversity into planning, (2) training and capacity-building in communities and BME populations, (3) achieving sustainability in the work of incorporating diversity into planning, (4) documenting the process and disseminating the results, and (5) networking. All these contributions could improve multicultural planning methodology. Moreover, learning alliances can become a sound approach to complement multicultural planning principles and methodology to meet the Equality Act's mandate in health services in the UK, as well as similar demands in other multicultural societies, if the observed methodological limitations are overcome. 
Learning alliances and multicultural planning can contribute to a deeper understanding of how individual and group-based differences are linked in health provision services at both organizational and institutional levels. Taking into account that social categories and identities are changing social constructs, their analysis and interconnectivity can help explain constructions of individual and group subjectivities, and study how these categories are used in health provision services and projects. Following feminist theorists such as Hartsock (1985) or Harding (2004) these research methodologies can explore the impact of the contextual position on a specific individual or group based on their identity markers, and focus on how particular positions both enable and delimit individual agency (Kaijser \& Kronsell, 2014, p. 422). In order to do this, Learning alliance and multicultural planning as methodologies need to be complemented by more systematic on-going qualitative research techniques that allow stakeholders to comprehend and navigate the complexity of health inequities, subjective contents, cultural practices, and power relations established among different individuals and social groups. As Bastia (2014) and Kaijser and Kronsell (2014) argue, it is not feasible to provide a step-by-step intersectional methodology or research technique. However, as suggested by Winker and Degele (2011) questions relating to social structures, symbolic representation, and identity construction should always be kept in the background during the research and planning process. These questions include "Which social categories, if any, are represented in the empirical material? Which social categories are absent? Are there any observable explicit or implicit assumptions about social categories and about relations between social categories? What identities are promoted and considered to serve as grounds for political action? Are any other aspects of identity neglected or deemed insignificant?" (Kaijser \& Kronsell, 2014, pp. 429-430). Furthermore, Matsuda (1991) suggests another set of questions: "When I see something that looks racist, I ask 'Where is the patriarchy in this?' When I see something that looks sexist, I ask 'Where is the heterosexism in this?'” (Matsuda, 1991, p. 1189). It is expected that these questions should help in maintaining awareness of various power positioning within intersecting identity relations. Nonetheless, this type of questioning has yet to be mainstreamed into planning theory and practice by urban stakeholders, academics, and practitioners (Irazábal \& Huerta, 2014; Tovar-Restrepo \& Irazábal, 2013).

The integration of anthropological and ethnographic qualitative research techniques such as participant observation, informal/formal interviews, life-stories, and focus groups with learning alliance and multicultural planning methodologies would allow urban planners and stakeholders to better elucidate local social and cultural dynamics that planning actions might target and transform. More specifically, integrating anthropologists and ethnographers into planning activities and settings would ensure more comprehensive and effective planning processes (Vargas-Cetina, 2013).

By focusing on local dynamics while adhering to more universal and general planning principles such as those established by the Equality Act, planners could promote healthier and more inclusive communities. Moving beyond identity politics to approaches that focus more on both the individual and multiple forms of discrimination and privilege, planners might attain a more accurate reading of the inherent complexity of identity and power relations. The Equality Act approach brings interesting challenges for planners, who need to question and complement "silo approaches", including multicultural planning, which has often used static and reified categories of identity and has regarded race and ethnicity as fixed and in isolation. In contrast, a learning alliance encourages planners to focus more on intervening in dynamic and changing social relations among diverse groups, rather than on static, homogenized sets of people or communities. As notions of difference are socially, historically, and locally constructed, planning methodologies will need to devise deft techniques to identify the complex and ever-changing dynamics taking place in the permanent constructions of senses of belonging, otherness, and autonomy (Tovar-Restrepo, 2012).

The persistent challenge of how to identify, target, and satisfy the needs of culturally different groups by equitably integrating them into a more inclusive society has no definitive solution. The 
fluid, changing, and complex nature of identity markers and their correlation with unequal power and social relations remain key challenges for any approach or methodology in planning. In the particular case of innovative methodological approaches in health service delivery for diverse ethno-racial groups this is a need not only in the UK but also in other multicultural societies. To remain relevant in today's world and respond effectively to the ethical mandate of socio-spatial justice that marks the discipline (Marcuse, 2012), planners are tasked with expanding and perfecting planning methodologies in multicultural settings (Umemoto \& Zambonelli, 2012). Although the learning alliance methodology is not the final answer, it contributes in this direction.

\section{Funding}

This project was funded by Diversity House and the South East Coastal Communities (SECC) project funded by the Higher Education Funding Council for England (HEFCE).

\section{Disclosure statement}

No potential conflict of interest was reported by the author(s).

\section{Notes}

1. The 2001 UK Census considered BME people as Indian, Pakistani, Mixed Race, Black Caribbean, Black African, Bangladeshi, Other Asian (non-Chinese), and Chinese. In the 2011 Census this category changed slightly to include gypsy and Irish travellers and Arabs in England and Wales only.

2. See the YouTube clip: "Olympic Opening Ceremony London 2012 NHS + Harry Potter + The Queen." http://www.youtube.com/watch? $\mathrm{v}=$ ONtpILzTRuI

3. In the UK context, GPs look after general health issues of local communities and provide referrals to specialists when needed. They are usually based at community health centres.

4. Even though this statement is valid - especially in Kent - it is important to note that in the case of Swale, local authorities did have some desegregated data available that were useful for the project. (Swale Borough Council, n.d.)

\section{Notes on contributors}

Carlos J. Moreno-Leguizamon is senior lecturer and programme leader in the MSc Research in Health and Social Care at the University of Greenwich (UK). He has a social sciences background in medical anthropology and health communication. His latest research projects relate to qualitative aspects in post-natal depression, chronic pain, inter-partner violence and end of life practices in black minority and ethnic groups in the UK, incorporating the learning alliance methodology.

Marcela Tovar-Restrepo conducts research on social exclusion, environmental justice and sustainable development. She serves as the Chair of the Board of Directors of the Women's Environmental and Development Organization (WEDO), New York, and teaches urban development at the Graduate School of Architecture, Planning and Preservation, Columbia University, New York.

Clara Irazábal is the Latin Lab Director and Assistant Professor of Urban Planning in the Graduate School of Architecture, Planning and Preservation at Columbia University, New York. In her research and teaching, she explores the interactions of culture, politics, and place-making, and their impact on community development and socio-spatial justice in Latin American cities and disenfranchised immigrant communities. Irazábal has published academic work in English, Spanish, Italian, and Portuguese. 
Christine Locke is Director of Diversity House (Swale, UK). She holds a MA in Community Cohesion Management and a MSc in Health Promotion and Public Health. She works on community development and heath services, risk management and stakeholder engagement.

\section{References}

Agyeman, J., \& Erickson, J. S. (2012). Culture, recognition, and the negotiation of difference: Some thoughts on cultural competency in planning education. Journal of Planning Education and Research, 32, $358-366$.

Anthias, F. (2002). Beyond feminism and multiculturalism:. Women's Studies International Forum, 25, 275-286.

Anthias, F., \& Yuval-Davis, N. (1983). Contextualizing feminism - Gender, ethnic and class divisions. Feminist Review, 15, 62-75.

Anzaldúa, G. (1999). Borderlands/La Frontera: The new mestiza. San Francisco, CA: Aunt Lute. (Original work published 1987).

Appiah, A., \& Gutmann, A. (1996). Color conscious: The political morality of race. Princeton, NJ: Princeton University.

Australian Public Service Commission. (n.d.). Multicultural plan 2013-15. Retrieved from http://www.apsc. gov.au/about-the-apsc/the-commission/multicultural-plan

Babatunde, T., \& Moreno-Leguizamon, C. (2012). Daily and cultural issues of postnatal depression in African women immigrants in south east London: Tips for health professionals. Journal of Nursing Research and Practice, 2012. doi:10.1155/2012/181640.

Bastia, T. (2014). Intersectionality, migration and development. Progress in Development Studies, 14, $237-248$.

Beebeejaun, Y. (2006). The participation trap: The limitations of participation for ethnic and racial groups. International Planning Studies, 11, 3-18.

Beebeejaun, Y. (2012). Including the excluded? Changing the understandings of ethnicity in contemporary English planning. Planning Theory \& Practice, 13, 529-548.

Blumenthal, D., \& Dixon, J. (2012). Health-care reforms in the USA and England: Areas for useful learning. The Lancet, 380, 1352-1357. Retrieved from http://www.sciencedirect.com/science/article/pii/ S0140673612609568

Brah, A., \& Phoenix, A. (2004). Ain't I a woman? Revisiting intersectionality. Journal of Women's International Studies, 5, 75-86.

Bubinas, K. (2005). Gandhi Marg: The social construction and production of an ethnic economy in Chicago. City \& Society, 17, 161-179.

Burman, E. (2003). From difference to intersectionality: Challenges and resources. European Journal of Psychotherapy \& Counselling, 6, 293-308.

Butterworth, J., McIntyre, P., \& da Silva Wells, C. (Eds.). (2011). SWITCH in the city: Putting urban water management to the test. The Hague: IRC International Water and Sanitation Centre. Retrieved from http:// www.switchurbanwater.eu/outputs/pdfs/SWITCH_in_the_City.pdf

Carpio, G., Irazábal, C., \& Pulido, L. (2011). Right to the suburb? Rethinking Lefebvre and immigrant activism. Journal of Urban Affairs, 33, 185-208.

Chau, R. C. M., \& Yu, S. W. K. (2009). Culturally sensitive approaches to health and social care: Uniformity and diversity in the Chinese community in the UK. International Social Work, 52, 773-784.

Clarke, S. E., \& Stokes, K. W. (2008, April). Political incorporation in a multicultural context: London boroughs. Paper presented at the Midwest Political Science Association Annual Meeting, Chicago, IL. Retrieved from http://citation.allacademic.com/meta/p268768_index.html

Community Cohesion Review Team. (2001). Community cohesion: A report of the independent review team. Chaired by Ted Cantle. London: Home Office.

Corburn, J. (2003). Bringing local knowledge into environmental decision making: Improving urban planning for communities at risk. Journal of Planning Education and Research, 22, 420-433.

Crenshaw, K. (1989). Demarginalizing the intersection of race and sex: A black feminist critique of antidiscrimination doctrine, feminist theory and antiracist politics. University of Chicago Legal Forum, $1989,139-167$.

Dargan, L. (2007). Conceptualising regeneration in the New Deal for Communities. Planning Theory \& Practice, 8, 345-362.

Dargan, L. (2009). Participation and local urban regeneration: The case of the new deal for communities (NDC) in the UK. Regional Studies, 43, 305-317, March 2009. 
Davis, A. Y. (1981). Women, race and class. London: Women's Press.

Department of Health. (2008). No patient left behind: How can we ensure world class primary care for black and minority ethnic people? Report of the group chaired by Professor Mayur Lakhani CBE. London: Department of Health.

Department of Health. (2009a). Kent health profile 2009. Retrieved from http://www.apho.org.uk/resource/ item.aspx?RID $=71454$

Department of Health. (2009b). Swale health profile 2009. Retrieved from http://www.apho.org.uk/resource/ item.aspx? RID $=71463$

Fainstein, S. S. (2000). New directions in planning theory. Urban Affairs Review, 35, 451-478.

Fraser, N. (1997). Justice interruptus: Critical reflections on the "postsocialist" condition. New York, NY: Routledge.

Friedmann, J. (1987). Planning in the public domain: From knowledge to action. Princeton, NJ: Princeton University.

Gotrett, M. V., Lundy, M., \& Ashby, J. (2005). Learning alliances: An approach for building multistakeholder innovation systems ILAC Brief No. 8. Rome: ILAC.

Greed, C. (2005). Overcoming the factors inhibiting the mainstreaming of gender into spatial planning policy in the United Kingdom. Urban Studies, 42, 719-749.

Harding, S. (2004). The feminist standpoint theory reader. Intellectual and political controversies. New York, NY: Routledge.

Harris, S. C., \& Irazábal, C. (2012). Transforming subjectivities: Service that expands learning in urban planning. In T. Angotti, C. S. Doble, \& P. Horrigan (Eds.), Service-learning in design and planning: Educating at the boundaries (pp. 107-124). Oakland, CA: New Village Press.

Hartsock, N. (1985). Money, sex and power. Toward a feminist historical materialism. Boston, MA: Northeastern University Press.

Hill Collins, P. (2009). Black feminist thought: Knowledge, consciousness, and the politics of empowerment. London: Routledge.

Inkpen, A. C. (2000). A note on the dynamics of learning alliances: Competition, cooperation, and relative scope. Strategic Management Journal, 21, 775-779.

Irazábal, C. (2011). Ethnoscapes. In T. Banerjee \& A. Loukaitou-Sideris (Eds.), Companion to urban design (pp. 562-573). London: Routledge, Taylor \& Francis.

Irazábal, C. (2012). Beyond 'Latino New Urbanism': Advocating ethnurbanisms. Journal of Urbanism: International Research on Placemaking and Urban Sustainability, 5, 241-268.

Irazábal, C., \& Farhat, R. (2008). Latino communities in the United States: Place-making in the pre-World War II, postwar, and contemporary city. Journal of Planning Literature, 22, 207-228.

Irazábal, C., \& Gómez-Barris, M. (2007). Bounded tourism: Immigrant politics, consumption, and traditions at Plaza Mexico. Journal of Tourism and Cultural Change, 5, 186-213.

Irazábal, C., \& Huerta, C. (2014). Community organizing and planning at the margins: LGBTQ youth of color in New York. Manuscript submitted for publication.

Irazábal, C., \& Punja, A. (2009). Cultivating just planning and legal institutions: A critical assessment of the South Central Farm struggle in Los Angeles. Journal of Urban Affairs, 31, 1-23.

Jojola, T. (2000, October). Indigenous planning and community development. Paper presented at the seventh IASTE Conference, Trani.

Jones, K. (2010). The Ethiopian immigrant business enclave in the United States: Perceptions of residents, consumers, and entrepreneurs. Journal of African Business, 11, 107-123.

Kai, J., \& Hedges, C. (1999). Minority ethnic community participation in needs assessment and service development in primary care: Perceptions of Pakistani and Bangladeshi people about psychological distress. Health Expectations, 2, 7-20.

Kaijser, A., \& Kronsell, A. (2014). Climate change through the lens of intersectionality. Environmental Politics, 23, 417-433.

Kent County Council, Eastern and Coastal Kent NHS Primary Care Trust, and West Kent NHS Primary Care Trust. (2007). Live life to the full. A strategy for public health in Kent 2007/2008.

Khanna, T., Gulati, R., \& Nohria, N. (1998). The dynamics of learning alliances: Competition, cooperation, and relative scope. Strategic Management Journal, 19, 193-210.

Kotin, S., Dyrness, G. R., \& Irazábal, C. (2011). Immigration and integration: Religious and political activism for/with immigrants in Los Angeles. Progress in Development Studies, 11, 263-284.

Koza, M., \& Lewin, A. (2000). Managing partnerships and strategic alliances: Raising the odds of success. European Management Journal, 18, 146-151. 
Krizsan, A., Skjeie, H., \& Squires, J. (2012). Institutionalizing intersectionality: The changing nature of European equality regimes. Bristol: Palgrave McMillan.

Lane, M. B., \& Hibbard, M. (2005). Doing it for themselves: Transformative planning by indigenous peoples. Journal of Planning Education and Research, 25, 172-184.

Locke, C. (2006). Swale African \& Caribbean consultation and needs assessment. Unpublished manuscript.

Locke, C. (2009). Community cohesion and black and ethnic minority communities health inequalities: A learning alliance experience in Kent. (Unpublished master's thesis). Coventry University, UK.

Loftman, P., \& Beazley, M. (1998). Race and regeneration. London: LGIU.

Lorde, A. (1985). I am your sister: Black women organizing across sexualities. New York: Kitchen Table, Women of Color Press.

Lutz, H., Herrera Vivar, M. T., \& Supik, L. (2011). Framing intersectionality: Debates on a multi-faceted concept in gender studies. Burlington: Ashgate.

MacLeavy, J. (2008). Managing diversity? "Community cohesion" and its limits in neoliberal urban policy. Geography Compass, 2, 538-558.

Maidstone Borough Council. (2011). Census 2011 briefing. Retrieved from http://www.maidstone.gov.uk/ council/performance-and-stats/2011-census, accessed July 2012

Marcuse, P. (2012). Justice. In R. Crane \& R. Weber (Eds.), The Oxford handbook of urban planning (pp. 1-40). New York, NY: Oxford University.

Marlor, C. (2010). Bureaucracy, democracy and exclusion: Why indigenous knowledge holders have a hard time being taken seriously. Qualitative Sociology, 33, 513-531.

Matsuda, M. J. (1991). Beside my sister, facing the enemy: Legal theory out of coalition. Stanford Law Review, $43,1183-1192$.

Maynard, M. (1994). "Race", gender and the concept of "difference" in feminist thought. In H. Afshar \& M. Maynard (Eds.), The dynamics of "race" and gender (pp. 9-25). Bristol: Taylor and Francis.

McCall, L. (2005). The complexity of intersectionality. Signs: Journal of Women in Culture and Society, 30, $1771-1800$.

McClinchey, K. A. (2008). Urban ethnic festivals, neighborhoods, and the multiple realities of marketing place. Journal of Travel \& Tourism Marketing, 25, 251-264.

McNay, L. (2008). Against recognition. Cambridge: Polity.

Miraftab, F. (2011). Faraway intimate development: Global restructuring of social reproduction. Journal of Planning Education and Research, 31, 392-405.

Miraftab, F., \& McConnell, E. D. (2008). Multiculturalizing rural towns - Insights for inclusive planning. International Planning Studies, 13, 343-360.

Moreno-Leguizamon, C., \& Spigner, C. (2011). Monitoring and evaluation of wellbeing projects. In A. Knight \& A. McNaught (Eds.), Understanding wellbeing: An introduction for students and practitioners of health and social care (pp. 50-66). London: Lantern Publishing.

Moriarty, P., Fonseca, C., Smits, S., \& Schouten, T. (2005). Background paper for the symposium: Learning alliances for scaling up innovative approaches in the water and sanitation sector. International Water and Sanitation Centre Delft, The Netherlands. Retrieved from http://www.cgiar-ilac.org/content/backgroundpaper-symposium-learning-alliances-scaling-innovative-approaches-water-and-sanita

Morrison, M., \& Mezentseff, L. (1997). Learning alliances - A new dimension of strategic alliances. Management Decision, 35, 351-357.

Nash, J. C. (2008). Re-thinking intersectionality. Feminist Review, 89(1-), 1-15.

Office for National Statistics. (n.d.). 2001 UK Census. Retrieved from http://www.ons.gov.uk/ons/guidemethod/census/census-2001/index.html

Office for National Statistics. (2003). Ethnic group statistics: A guide for the collection and classification of ethnicity data. Retrieved from https://www.google.co.uk/?gfe_rd=cr\&ei=AsRcVLv2Gs6q8weo 04LYAg\#q=ethnic + monitoring + Commission + for + Racial + Equality

Penning de Vries, F. W. T. (2006). Learning alliances for the broad implementation of an integrated approach to multiple sources, multiple uses and multiple users of water. Water Resources Management, 21, 79-95.

Porter, L. (2010). Unlearning the colonial cultures of planning. Farnham: Ashgate.

Qadeer, M. A. (2009). What is this thing called multicultural planning? Plan Canada (pp. 10-13). Retrieved from http://canada.metropolis.net/pdfs/qadeer_extracted_plan_canada_e.pdf

Qadeer, M. A., \& Agrawal, S. (2011). The practice of multicultural planning in American and Canadian cities. Canadian planning and policy [Special issue]. Canadian Journal of Urban Research, 20, 132-156.

Ram, M., Abbas, T., Sanghera, B., \& Hillin, G. (2000). Currying favour with the locals: Balti owners and business enclaves. International Journal of Entrepreneurial Behaviour \& Research, 6, 41-55. 
Salway, S., Platt, L., Chowbey, P., Harriss, K., \& Bayliss, E. (2007). Long-term ill health, poverty and ethnicity. York: Joseph Rowntree Foundation.

Sandercock, L., \& Lyssiotis, P. (2003). Cosmopolis II: Mongrel cities in the 21 st century. London: Continuum.

Sandoval, G. F. (2013). Shadow transnationalism: Cross-border networks and planning challenges of transnational unauthorized immigrant communities. Journal of Planning Education and Research, 33, $176-193$.

Smith, D., \& Ruston, A. (2009). Travellers health. South East Coastal Communities Project. Unpublished manuscript.

Smits, S., Moriarty, P., \& Sijbesma, C. (Eds.). (2007). Learning alliances scaling up innovations in water, sanitation and hygiene (Technical Paper Series 47). Delft: IRC International Water and Sanitation Centre. Retrieved from http://www.ircwash.org/resources/learning-alliances-scaling-innovations-watersanitation-and-hygiene

Spivak, G. (1988). In other worlds: Essays in cultural politics. New York, NY: Routledge.

Swale Borough Council. (n.d.). Toward a fairer Swale: Corporate equality strategy 2007-2011. Retrieved from http://www.swale.gov.uk/assets/Strategies-plans-and-policies/Equality-Strategy-WEB.pdf

Sweet, E. L., \& Etienne, H. F. (2011). Commentary: Diversity in urban planning education and practice. Journal of Planning Education and Research, 31, 332-339.

Thomas, H. (2000). Race and planning: The UK experience. London: UCL.

Tovar-Restrepo, M. (2012). Castoriadis, Foucault, and autonomy: New approaches to subjectivity, society, and social change. London: Continuum.

Tovar-Restrepo, M. (2014). Nations within nations: Transnationalism and indigenous citizenship in Latin America. In C. Irazábal (Ed.), Transbordering Latin Americas: Liminal places, cultures, and powers ( $t)$ here (pp. 149-165). New York, NY: Routledge, Taylor \& Francis.

Tovar-Restrepo, M., \& Irazábal, C. (2013). Indigenous women and violence in Colombia: Agency, autonomy, and territoriality. Latin American Perspectives, 41, 1-20.

Umemoto, K. (2001). Walking in another's shoes: Epistemological challenges in participatory planning. Journal of Planning Education and Research, 21, 17-31.

Umemoto, K., \& Zambonelli, V. (2012). Cultural diversity. In R. Crane \& R. Weber (Eds.), The Oxford handbook of urban planning (pp. 1-40). New York, NY: Oxford University Press.

Valentine, G. (2007). Theorizing and researching intersectionality: A challenge for feminist geography. The Professional Geographer, 59, 10-21.

Vargas-Cetina, G. (2013). Anthropology and the politics of representation. Tuscaloosa: University of Alabama.

Vazquez, L. (2009). Principles of culturally competent planning and placemaking. Retrieved from http:// placemakerhub.blogspot.com/2009/11/principles-of-culturally-competent.html

Verhagen, J., Butterworth, J., \& Morris, M. (2008). Learning alliances for integrated and sustainable innovations in urban water management. Waterlines, 27(2), April 2008. Retrieved from http://wedc.lboro. ac.uk/resources/conference/33/Verhagen_J.pdf

Winker, G., \& Degele, N. (2011). Intersectionality as multi-level analysis: Dealing with social inequality. European Journal of Women's Studies, 18, 51-66.

Yau, P., \& Turle, M. (2005). Needs assessment of Chinese people in Swale. Unpublished manuscript.

Yiftachel, O. (1998). Planning and social control: Exploring the dark side. Journal of Planning Literature, 12, $395-406$.

Yiftachel, O. (2009). Critical theory and "gray space": Mobilization of the colonized. City, 13, 246-263.

Yuval-Davis, N. (2007). Intersectionality, citizenship and contemporary politics of belonging. Critical Review of International Social and Political Philosophy, 10, 561-574. 